\title{
Virtue, Situationism, and the Cognitive Value of Art $^{1}$ Jacob Berger, Idaho State University Mark Alfano, Delft University of Technology
}

Published in The Monist (2016), 99, 2: 144-158.

Penultimate draft. Please quote from the published version.

\begin{abstract}
Virtue-based moral cognitivism holds that at least some of the value of some art consists in conveying knowledge about the nature of virtue and vice. We explore here a challenge to this view, which extends the so-called situationist challenge to virtue ethics. Evidence from social psychology indicates that individuals' behavior is often susceptible to trivial and normatively irrelevant situational influences. This evidence not only challenges approaches to ethics that emphasize the role of virtue but also undermines versions of moral cognitivism, because the value of art cannot consist in teaching us about traits that do not exist. We thus recommend a new account of the cognitive value of art: art teaches how context and character interact to produce action.
\end{abstract}

Keywords: art; knowledge; situationism; virtue

\section{Introduction}

\footnotetext{
${ }^{1}$ Both authors contributed equally to this manuscript.
} 
What is the value of art? Many philosophers of art today follow the Aristotelian tradition of cognitivism: the view that at least some of the value of some art consists in its capacity to impart knowledge to its audience (Graham 1996; Young 2001; Gaut 2006). Let us call that knowledge the cognitive value of art. $^{2}$ Cognitivists disagree about the content of the knowledge that art conveys. One promising version, which we will term moral cognitivism, holds that art educates about morality (Currie 1995; Kieran 1996, 2005; Carroll 1998, 2002, 2013; Conolly and Haydar 2001).

Moral cognitivism has been variously challenged, ${ }^{3}$ but here we consider a critique that has not been adequately explored. To the extent that moral cognitivism holds that some of the value of art consists in its capacity to teach the nature of virtue and vice, the view is open to an objection - an elaboration of the so-called situationist challenge to virtue ethics. This challenge marshals evidence from social psychology indicating that people's behavior is often surprisingly susceptible to trivial and normatively irrelevant situational influences. If the cultivation of virtue (or vice) were psychologically unrealistic, then it would seem that ethical theories on which virtue plays a central role are undermined. ${ }^{4}$ If this argument succeeds, moral cognitivism is

${ }^{2}$ Cognitivism as we construe it is consistent with pluralism regarding the value of art, allowing that some of the value of art may also reside, for instance, in its purely formal properties (see Kant 1790/1952; Beardsley 1958).

${ }^{3}$ For discussion and reply to several of these criticisms, see Carroll 2002.

${ }^{4}$ For discussions of virtue ethics and this kind of challenge to it, see Doris 1998, 2002; Harman 1999, 2000; Miller 2003, 2009; Alfano 2011, 2013. 
likewise threatened. After all, art cannot succeed through teaching us about virtue or vice if such character traits do not exist or if they are unattainable ideals.

The only paper replying to this challenge in the domain of art is a recent article by Noël Carroll (2013), who argues that art need not teach us how actual virtuous or vicious people $d o$ act; instead, art may teach us how people of such character would act-and thus providing us with models of moral behavior. While we find Carroll's proposal instructive, we contend that it faces several difficulties. Rather than rejecting moral cognitivism, we propose an alternative account on which the cognitive value of art is best construed as interactionist: art teaches not only how virtuous people do or would act, but also how context and character interact to produce conduct. We thus recommend a new account of the value of art, which we illustrate with examples from literature and television. ${ }^{5}$

\section{Moral Cognitivism Introduced}

The idea that art provides knowledge is rooted in Aristotle, who urged that the poet, unlike the historian who depicts only how things did happen, depicts much more than what actual persons have actually done. Aristotle maintained that part of the value of narrative art is to reveal how people of certain sorts would act in similar circumstances (e.g., 1984, 1451a371451b8). To borrow his example, while the play Antigone concerns Creon and Antigone as

\footnotetext{
${ }^{5}$ We focus here on narrative art—and in particular the role of characters in narrative art—rather than non-narrative forms such as painting, because of narrative's capacity to showcase character from multiple angles. However, we think our argument applies to non-narrative representations of character as well.
} 
specific persons, the audience learns facts about human nature that go beyond them as individuals. We learn that strong-willed people with incompatible aims are prone to catastrophic clashes. As Carroll explains, for Aristotle "poetry tells us what certain kinds of people - people with this or that character-structure-are likely to say (to decide) and to do in certain situations" $(2013,66)$.

Moral cognitivism takes this view one step further, maintaining that artists not only represent facts about how particular characters or character-structures behave, but also provide facts about morality. Art furnishes us with models of moral lives, revealing how its audience members ought to think, feel, decide, act, and flourish (or founder). But what is the content of the moral knowledge conveyed by art and how can it be extracted? Here we can distinguish varieties of moral cognitivism by the content of the moral knowledge they recognize.

First, one could hold that art educates about the deontological: art teaches what is permissible, obligatory, and forbidden — perhaps with an eye to the universalizability of motives. Second, one could hold that the moral content of art is consequentialist: art shows us which states of the world are good and bad, better, worse, and optimal. Thomas More's Utopia, Soviet socialist realism, and dystopic science fiction might serve as examples. Third, one might claim that art illustrates the ethics of care. Zora Neale Hurston's Their Eyes Were Watching God might be a paradigm.

Perhaps the most attractive and most prominent version of moral cognitivism holds that the moral content of art is virtue ethical: art teaches its audience the subtleties of virtue and vice and the ways in which they interact to produce characteristic patterns of behavior. Art elaborates in narrative form the perception, thought, feeling, deliberation, and behavior of moral exemplars (Zagzebski Forthcoming). Homer's Iliad is an investigation of the strengths and weakness of 
mêtis (artifice), as exemplified by Odysseus, and biê (might), as exemplified by Achilles (Nagy 1979, 45). Spenser devotes each book of the Fairie Queene to the narrative elaboration of a particular virtue embodied by a specific personage. Our discussion centers on this virtue-based version of moral cognitivism. ${ }^{6}$ As we understand the view, one of the prime functions of characters in narrative art, in virtue of which lies at least some of its value, is to present opportunities for the audience to learn not only what virtuous or vicious people do or would do, but also why they themselves should act virtuously and avoid vice.

Another kind of distinction among varieties of moral cognitivism regards the question of what the cognitive content of art is supposed to accomplish. According to Carroll's $(1998,142)$ so-called clarificationist view, art does not provide new information about morality, but helps the audience to clarify in a vivid way known facts about morality. By providing concrete examples of people acting virtuously or viciously, art seemingly enables its audience to develop a deeper understanding of what otherwise would remain relatively abstract moral notions. For example, observing Sir Guyon over the course of a whole book of the Fairie Queene affords a nuanced picture of the virtue of temperance.

Oliver Conolly and Bashar Haydar $(2001,109)$, by contrast, defend what they call propositionalism - the view that art can provide us with fresh propositional knowledge of moral

\footnotetext{
${ }^{6}$ It is of course possible to subscribe to combinations of versions of moral cognitivism or even to hold an interactive view according to which art teaches us how, for instance, deontological and consequentialist proscriptions might interact and perhaps clash. Sophie's Choice might be an example. Our critique extends to any version of moral cognitivism that includes information about virtue and vice within the domain of art's cognitive value.
} 
facts. Seeing Creon and Antigone in conflict teaches the audience new truths about how principled persons might collide. Our arguments here apply to both clarificationist and propositionalist varieties of virtue-based moral cognitivism, since both views assume that the content of the moral component of the cognitive value of art is knowable and hence true.

It would seem that art is particularly well suited to perform this instructive function. Martha Nussbaum $(1996,12)$ famously maintains that literature is an ideal medium of moral education because narratives explain and evaluate characters' behavior in both descriptive and normative ways. Because art is couched in these terms, it has the power to entice empathic readers to follow the models depicted. Likewise, Daniel Hutto (2009) has recently proposed that we make sense of our own and one another's conduct by constructing narratives in which people act for reasons, and that children only learn to make sense of human conduct by engaging in such narrative construction themselves. Art therefore bolsters a natural mechanism through which we relate empathically to ourselves and to others.

Crucially, Carroll maintains that art can perform this educative function precisely because the characters in narratives behave as actual people do and would — and so provide models of moral behavior. He writes that moral cognitivism "holds that fictional characters provide us with social information that we can apply to the world because fictional characters possess characterstructures like those of actual people" (2013, p. 70, emphasis his). But herein a challenge lies.

\section{The Situationist Critique of Virtue Ethics}

To the extent that art is supposed to teach us about virtue and vice, moral cognitivism is open to a criticism based on a prominent critique of virtue ethics, which we will now briefly review. The emphasis of virtue ethics falls not on the rightness or wrongness of actions or the 
universalizability of motives, but on the sorts of people we ought to be (e.g., Aristotle 1984; Hursthouse 1999; Annas 2011). According to virtue ethics, a good person is someone who cultivates and exercises virtuous character, manifesting such qualities as wisdom, courage, generosity, honesty, and the like. Virtues are dispositions to notice, construe, prefer, deliberate, and act in characteristic ways. Courage, for example, is a disposition to respond to cues of danger astutely and to overcome these threats whenever possible.

Virtue ethicists maintain that these character traits must be deeply ingrained in specific ways. John Doris $(2002,22)$ spells out this idea in terms of the consistency, stability, and evaluative integration of character traits. Consistency entails reliable manifestation in diverse conditions. The honest person not only does not lie to his mother about money, but also does not lie to his friends about current events, nor does he cheat or steal. Stability entails reliable manifestation over repeated trials in similar circumstances. The courageous person is someone who responds and would respond successfully to the same type of threat today, tomorrow, and next year. Evaluative integration entails that possessing one virtue makes it more likely that one possesses other virtues. The open-minded person is more inclined to be humble than the closedminded person. Of course, blindly following a rule such as, "give to others" can easily go astray. Virtuous examplars are able to respond in nuanced ways to situations where competing values are at stake.

One of the most innovative contemporary challenges to virtue ethics has been the attempt to marshal evidence from situationist social psychology against the empirical adequacy of the virtue-ethical conception of character. As Doris construes it, situationism is the view that "behavioral variation across a population owes more to situational differences than dispositional differences among persons," that "people will quite typically behave inconsistently with respect 
to the attributive standards associated with a trait," and that "evaluatively inconsistent dispositions may 'cohabitate' in a single personality" (2002, 24-25). According to situationism, consistency and evaluative integration do not characterize the psychological lives of most individuals.

Social psychology over the last half-century presents a large body of evidence in favor of situationism. A classic example is John Darley and Daniel Batson’s (1973) so-called "Good Samaritan" study, conducted with students from the Princeton Theological Seminary. Participants were asked to prepare a talk focused on either job prospects for seminarians or the scriptural parable of the Good Samaritan, in which a robbed and beaten man is ignored by a lofty Levite priest but helped by a lowly Samaritan. The moral of the story is that one should emulate the compassionate Samaritan, not the sanctimonious clergyman. Presumably the seminarians were familiar with this moral lesson, and presumably they aimed to live by it.

To test whether or not the seminarians would themselves act on the lesson of the Good Samaritan, Darley and Batson arranged for each of them to encounter a distressed confederate slumped on the ground along the path to the location where they would give their talks. Some seminarians were informed that they had time to spare, others that they were running late. The experimenters covertly observed whether the participants stopped to help the distressed confederate, as the Good Samaritan had done. Perhaps surprisingly, the assigned subject of the participants' speech did not correlate with a willingness to help; the degree of hurry accounted almost entirely for the observed differences in behavior. Despite the fact that they were reenacting the very parable about which they were about to lecture, a huge majority of the rushed seminarians $(90 \%)$ failed to show compassion to the distressed confederate. By contrast, those who were not hurried stopped to offer help $63 \%$ of the time. 
This example is proffered not as an argument for situationism, but as an illustration of the sort of evidence that situationists bring to bear against a robust notion of character. In light of such evidence, situationists claim that while people's personalities do differ in important ways (after all, some seminarians helped even when hurried or failed to help even when unhurried), such differences are neither as robust as we tend to assume nor sufficiently robust to support the explanatory and predictive work that character traits are meant to do. The ceiling for the correlation between personality variables and behavior, including morally evaluable behavior, is around 0.30 (Mischel 1968). By contrast, the correlation between situational factors and behavior-from mood elevators and mood depressors to ambient sensory stimuli and the presence of bystanders - is sometimes as high as 0.40 (Funder and Ozer 1983) and consistently higher than the correlations for personality variables (Rauthmann et al 2014). Thus, while something like character may exist, it is a pale reflection of the robust sort of character that virtue ethicists usually presuppose.

Philosophers such as Doris and Gilbert Harman $(1999,2000)$ have brought this sort of psychological evidence to bear on virtue ethics. ${ }^{7}$ What the situationist evidence suggests is that most individuals do not exhibit, and are seemingly unable to exhibit, the kinds of deeply ingrained personality traits that virtue ethics requires of its exemplars. Slight changes to situational contexts generate great disturbances in the behavioral profiles of ordinary people. If character traits are unlike the virtual-ethical conception of them, then it appears that there are no

\footnotetext{
${ }^{7}$ See Alfano (2013) for a summary and evaluation of the debate since 2002.
} 
such things as virtues, or at least that virtues are quite rare. Consequently, being a good person cannot be dependent upon developing such virtues, lest (almost) no one be good. ${ }^{8}$

Contemporary psychology has largely resolved the person-situation debate in favor of what is known as interactionism, a view which grants roughly equal weight to character and situation as drivers of action (Reynolds et al 2010). Interactionism holds not that character is totally impotent, but that it is both much less influential than people ordinarily suppose and much less influential than it would need to be in order to explain behavior on its own. It is beyond the scope of this paper to evaluate whether and to what degree the situationist challenge to the psychological reality of virtue succeeds. In what follows, the question we will explore is: If the situationist challenge succeeds — that is, if virtue is uncommon or even nonexistent — what are the implications for moral cognitivism?

\section{Extending the Situationist Critique to Moral Cognitivism}

${ }^{8}$ A common virtue-ethical reply is that while virtue may be rare, it is nonetheless real (see Miller 2003, 379; Swanton 2003, 30). Even if not all participants in the Good Samaritan study stopped to help the seemingly ailing confederate, $10 \%$ of them did so-so perhaps those compassionate few are virtuous after all. It's arguable, however, that even those few participants could have been influenced in other circumstances by other morally irrelevant situational variables. Perhaps they are not as susceptible to situational influence as their fellow participants, but nonetheless do not exhibit robust virtue. And even if a lucky few are virtuous, virtue ethics would still be broadly psychologically unrealistic insofar as the majority of people appear heavily influenced by situational factors. 
The situationist critique has been extended to other debates in philosophy such as aspects of virtue epistemology (Alfano 2012, 2013), but until now there has been almost no discussion of its implications for the philosophy of art. Just as virtue ethics and virtue epistemology may need to be revised to accommodate situationist insights into human nature, so too may our theories of art need to be reframed in light of these considerations.

We can distinguish two related questions about how the situationist critique applies to moral cognitivism. First, there is the question of whether or not the moral content of art accurately represents what does or could obtain in the real world. Here, the application of the critique is straightforward. Moral cognitivists maintain that Homer's depiction of Achilles reflect courage as it can and should be manifested in actual people. Thus, if situationism is true, to the extent that art depicts virtue as widespread or widely attainable, its moral content is at best misleading and at worst false. One might argue that art depicts moral exemplars-and that some people can in fact achieve genuine virtue. But such persons are very difficult if not impossible to find. Furthermore, art that fails to represent the interaction of personality with situational influences paints a misleading picture of actual human moral psychology. As Adam Morton puts it in a related context:

[W] hen we respond to fiction we react to the characters in many of the ways we do to real people, and so if a way of reacting makes sense with respect to a fiction, we tend to think that it makes sense with respect to real people. This can have two bad consequences. It can give us the impression that a certain kind of personality is possible, when in fact real humans cannot be that way. Or, alternatively, it can give us an impression that some kind of action is often caused by some kind of motive, or that some motive is a plausible cause of some kind of action, when in fact this is psychologically wrong. I am sure that both 
illusions are quite common, and should make us wary of claims that fiction educates us about human nature (2013, 83-84).

If the moral content of art is false or misleading in this way, it becomes hard to see why it deserves to be called the cognitive value of art. ${ }^{9}$

The question of whether or not the moral content of art is accurate is independent of a second question - namely, does exposure to art, whether accurate or not, inculcate a useful knowledge of virtue in its audiences? Even if The Iliad misrepresents the ubiquity of courage, could it not teach people about the nature of courage? In this regard, the application of the situationist critique is more complicated. If the situationist critique succeeds, art furnishes its audience with many false beliefs about morality and human conduct generally. It is thus difficult to see how such beliefs could be useful guides for moral behavior. Audiences would presumably come away from art with the erroneous notion that they can and should cultivate consistently good character. They may believe that virtues can be acquired when these traits may be impotent in the face of situational influences, regardless of how assiduously they are cultivated. Likewise, the models of virtue and vice described by art rarely if ever resemble the behavior of actual people - and so it is unclear how consumers of art could utilize those unrealistic portraits to judge whether actual individuals deserve praise or blame.

\footnotetext{
${ }^{9}$ Of course, narratives put demands on what characters can and cannot do in works of art to forward the plot—and so there may be many kinds of constraints on what characters in particular works or even in general can teach. Whatever these additional constraints may be, both virtue and vice are extremely rare or fictional, so art that depicts a wide variety of virtues and vices distributed across its characters typically misrepresents psychological reality.
} 


\section{Carroll's Moral Cognitivism}

Carroll recently attempts to defend moral cognitivism from the kind of situationist criticism developed above. He acknowledges that the situationist evidence suggests that art cannot teach us how virtuous or vicious people do act, but replies that art may still convey or clarify how people with certain character traits would act. Art thus provides us with a model for how we ought to strive to behave and furnishes us norms with which we can evaluate our own conduct and the acts of others:

Characters - such as those found in the great myths and later in the fictions (and especially the popular fictions) of secular culture — are a crucial, recurring mechanism for imparting social information about the way in which members of that culture, given their role or station in it, should comport themselves. In this fashion, fictional characters function to provide norms for evaluating ourselves and others $(2013,72)$.

Odysseus, his encounter with the sirens notwithstanding, is depicted as resistant to situational influences and is in that way unlike actual human beings. But Odysseus can nonetheless function as a model of cunning, courage, and leadership. While perhaps no one can be as cunning as Odysseus, we learn from reading the Odyssey what ideal cunning looks like. We learn that when one fails to act as Odysseus does, one falls short in relation to the ideals of cunning and courage. Though arguably no one can be immune to situational variables, being taught about an unrealistically virtuous person promotes better engagement with the idea of virtue.

This is an intriguing view and there is doubtless much to recommend it, but as Carroll himself acknowledges, it may require clarification or revision. In what follows, we explore a few 
difficulties with Carroll's proposal, and then propose our own view of the moral content of the cognitive value of art.

Perhaps the most obvious difficulty with Carroll's view is that if characters in art provide models of good conduct and yet most or all people are unable to emulate those models, then characters set overly demanding moral standards. Carroll claims that we can use these norms to evaluate people's behavior "whether they live up to those norms or fail" $(2013,72)$. But if personality variables account for so little behavioral variance, most or perhaps all people will fail to live up to such ideals. The standards that art putatively teaches us, then, seem to violate the widely accepted dictum that ought implies can. Though one might question the validity of this principle, it would be strange to think that art frequently models for us people whom we cannot emulate and provides norms that we can (almost) never live up to.

One might reply that aspiring towards unattainable ideals would nonetheless point people in the right direction. Since character traits are not wholly impotent in the face of situational factors, there must be some value to acquiring them. Moreover, people arguably can be more or less virtuous. If some of the variance in behavior is due to personality factors, then aspirational elements in art carry the hope of bolstering that component, teaching us what we can strive for and how to do so. Or perhaps art can ensure that the input of personality aims at virtuous rather than vicious conduct.

But if robust virtue does not exist in the world, then artistic models of such virtue plainly do not furnish people with the information that they would need to achieve that level of virtue. And even if some truly virtuous people do exist, it is unclear how helpful artistic depictions of paragons of virtue might be for ordinary mortals. Indeed, portraying largely unattainable models may even backfire. As the psychology literature on the phenomenon known as self-handicapping 
reveals (Arkin et al 1998), people who impressed with the great difficulty of a task before them often act in self-defeating ways to prevent the possibility of failure. Thus if the norms conveyed by art are too demanding, audiences might wrongly conclude that attaining a richly moral life is out of reach. If one knew that one could never act as courageously as Odysseus, one might conclude that one should never attempt to be courageous at all. Alternatively, if one incorrectly believes that one has cultivated a particular virtue, one may act in ways that call for the exercise of a virtue that one actually lacks. As Doris (2002, 112 and 149-152) observes, if someone incorrectly believes that he has cultivated the virtue of fidelity, he may foolishly place himself in compromising situations. Likewise, by obscuring the important role played by situation in determining behavior, a work of fiction might mislead its audience to ignore the vicissitudes of situation when attempting to act morally or when interpreting and evaluating the behavior of others. In other words, the audience could end up in even worse shape than it might have been without art.

One might instead defend the artistic representation of unattainable ideals by arguing that art nevertheless has value because it brings character traits into relief by depicting exaggerated versions of character. If artists are interested in educating audiences about personality, then it seems that they may legitimately elide the influence of situation. Such selective representation might be justified on the grounds that when one wants to showcase certain properties, one may emphasize them in ways that distort the facts on the ground. The tragedian puffs up the headstrong personalities of Creon and Antigone while deflating the situational influences that partially govern behavior because the main object of interest is the clash of strong-willed individuals. After all, representations of any kind invariably elide certain aspects or properties of 
the object represented. A topographical map may represent elevation while omitting flora, fauna, political boundaries, weather, or wealth distributions.

Relatedly, one could argue that art accurately depicts virtue because it represents the most extraordinary of individuals. Aristotle himself justified the exaggeration of character features in tragedy because, he claimed, it essentially concerns those who are unusual:

As tragedy is an imitation of personages better than the ordinary man, we should follow the example of good portrait painters, who reproduce the distinctive features of a man, and at the same time, without losing the likeness, make him handsomer than he is (1984, 1454b8-1454b11).

It is plain that art frequently catalogues the exploits of the extraordinary rather than the ordinary. Our favorite novels and movies focus on the exploits of valiant heroes and base villains: those special few who break the everyday mold. Perhaps, then, art focuses on those rare figures that manage to exhibit robust character, despite their situations. In that way, the moral content of art might be true - it accurately depicts rare virtue and can educate those few who are able to achieve it.

But this kind of purposeful exaggeration of or attention to personality would have its costs. Most obviously, it would massively restrict the nature of the cognitive value of art and the audiences capable of benefitting from it. Art's moral content would concern itself only with a rarified few and likewise be accessible or useful only to a rarified few.

Moreover, presenting moral exemplars is arguably not the best way to educate people about the reality of character. It may, for example, be better to concentrate on the mistakes one needs to avoid, given one's personality and the situations in which one is likely to find oneself. If that is correct, art might better educate us by presenting negative rather than positive role 
models. A negative role model for $\mathrm{X}$ is someone who is similar enough to $\mathrm{X}$ in important respects, whom $\mathrm{X}$ admires, but who also suffers from weaknesses and limitations to which $\mathrm{X}$ is vulnerable. X can empathize with her negative role model more easily than a positive role model, and $\mathrm{X}$ can use that empathic connection to better understand and flag moments when she is liable to fail to live up to her own standards. As Mark Alfano (2015) argues, we tend to know what a negative role model would do better than what a positive role model would do. Asking yourself, "What would Achilles do?" may not be much help, but asking yourself, "What mistake might my roommate make?" may prompt an answer.

Even if much art does exaggerate character or depict the extraordinary, it need not do so in order to teach moral lessons. Perhaps some works, such as The Odyssey, catalogue the exploits of the heroic and unusual. Other works, such as Thornton Wilder's Our Town, depict everyday human beings. Some, such as Sophocles, exaggerate character or focus on the few who exhibit robust character. Other artists are sensitive to the influence of situational factors. In The Stranger, for example, Albert Camus describes how a surfeit of sunlight could lead to murder: I was conscious only of the cymbals of the sun clashing on my skull, and, less distinctly, of the keen blade of light flashing up from the knife, scarring my eyelashes, and gouging into my eyeballs. . . a great sheet of flame poured down through the rift. Every nerve in my body was a steel spring, and my grip closed on the revolver (1942/1946, 38-39). While Antigone may teach a moral lesson because it exaggerates character or elides the situation, it would be false to say that The Stranger fails to teach us anything about morality because it emphasizes the power of situations or elides the importance of character. So even if Carroll were right that some of art's value consists in presenting characterological norms, art has far more to offer. 
Carroll of course recognizes that not all art depicts the extraordinary (e.g., 2013, 79). Moreover, he emphasizes that his account of the cognitive value of art is but "one way of defending... the common view that we derive social information from fictional characters" and that there may be "other defenses to be pursued" (2013, 65, emphasis his). Thus in the next section, we present and defend a new version of moral cognitivism, which might be read as a friendly amendment to Carroll's view.

\section{Interactionist Cognitivism about the Value of Art}

Again, the psychological evidence suggests that situations often have as much or even more influence on our behavior as the character endowment we may possess. What the situationist critique renders vivid is the fact that we are all embodied beings operating within particular situational contexts.

Instead of ignoring or downplaying these facts, moral cognitivists may enshrine them within art's cognitive value: art may teach us the myriad ways in which character and situation interact. Thus we propose what we call interactionist moral cognitivism, according to which art can and should educate us about the interplay of context and character in producing behavior. And, we contend, some of this interplay will inevitably involve the influence on conduct of

seemingly trivial and normatively irrelevant situational factors. On this view, art represents both how people do act and how they would act given various permutations of characters and situations. Furthermore, art need not represent individuals as being unrealistically virtuous or vicious, nor is art impelled to showcase unrealistic norms.

Interactionist cognitivist is pluralist. We deny neither that art often depicts the normative ideals of moral heroism and sainthood, nor that it often focuses on or exaggerates facts about 
personality. But interactionist cognitivism claims that much of art's value consists in presenting facts about the interaction of person and situation.

Interactionist cognitivism holds that art educates along both moral and factual dimensions. On the factual dimension, art may encode knowledge of the frailty of character and the ways in which character and context interact. An audience could learn from art that situations play a greater role in determining what we do than we might initially suppose and that the power of our personalities can go only so far. By dramatizing our inability to transcend situational influences, art might disabuse us of the mistaken notion that we will always act in accordance with our character. This is the lesson that can be drawn through watching The Experiment, the documentary-style dramatization of Stanley Milgram's (1974) infamous investigations of obedience to authority. ${ }^{10}$

On the moral dimension, art may educate us about realistic norms. Art reveals, for instance, how people ought to behave given the limits of character. By seeing a generally courageous fictional character succumb to situational influences in, for example, the film Platoon, one can learn what realistic courage looks like. Art can teach us that some situations may make the best of us act wrongly.

Indeed, there is some evidence from psychology that suggests that this mechanism within art could furnish people with information about how to effectively act morally. In a recent article, Alfred Mele and Joshua Shepherd (2013) argue that knowledge of the typical situational influences on behavior can boost people's agency. Citing the experimental work of Peter Gollwitzer (1999), they observe that the formation of so-called implementation intentions-

\footnotetext{
${ }^{10}$ For a virtue-ethical perspective on this experiment, see Badhwar 2009.
} 
intentions not to perform a particular goal, but that specify how to achieve a goal—can counteract situational influences. In one study, $100 \%$ of participants who were asked to perform breast self-examinations in the coming month did so if they were instructed to form additional implementation intentions as compared to the $53 \%$ of the control group who received no additional instructions (Gollwitzer 1999, 496, cited on 2013, 77). Knowledge about the ways in which situation might influence behavior arguably mitigate those influences. Thus art that provides us with information about how situation shapes our characters and actions could reinforce the achievement of realistic virtue.

It is important to distinguish this view from what some regard as Aristotle's position. We described Aristotle as holding that character is a matter of certain kinds of personality types showing propensities to behave in certain ways. But it might be that the Aristotelian notion of character involves broader situational factors. As Carroll conceives of Aristotle's view, particular characters in art are embodiments of character-structures, ideal types that arguably involve various situational features or concerns. A character like Creon represents the claims of the state - and so his character includes situational reference points such as his social role and its interactions with other social roles. Regardless of Creon's particular personality quirks, the audience learns that human beings in his position of power tend to act in certain ways.

Such a view of character has a parallel in the virtue-ethical literature. Robert Merrihew Adams (2006, 138-142), for example, has argued that affiliations and social roles themselves constitute virtues or vices. Friendship and participation in forms of kinship (e.g., filial piety) may be virtuous and membership in odious organizations (e.g., the Ku Klux Klan) may be vicious. Whether or not this intriguing reading of Aristotle's conception of character is apt, one might think that it responds to the situationist critique in the same way as interactionism. 
Interactionism differs from positions that build situational features into character. Even granting Adams' or Aristotle's position, we can observe a host of influential situational variables (e.g., lateness, pharmacological mood elevators, or ambient sounds and smells) that have nothing to do with such affiliations or social roles. Thus the situationist critique still applies to such views. Interactionism, by contrast, holds that in addition to morally relevant aspects of situation such as one's social station, art can educate about drivers of behavior that are morally and socially irrelevant.

Many artworks, such as Jane Austen's novels, explicitly explore the interplay between character and context. In Persuasion, we read, "Sir Walter. . [had] been flattered into his very best and most polished behavior by Mr. Shepherd's assurances of his being known, by report, to the Admiral, as a model of good breeding" $(1818 / 2012,21)$. Sir Walter is sometimes boorish, sometimes polished. He cares a great deal how he is viewed by his social superiors, such as the Admiral, so when he is informed that the Admiral expects him to behave courteously, he lives up to those expectations. This is a phenomenon that Alfano (2013, chapter 4) has called factitious virtue, which emerges when someone behaves in accordance with a character trait not because he possesses the trait but because he thinks that others expect it of him.

Richard Wright's novel Native Son powerfully illustrates the contrary phenomenonwhat Alfano (2013, chapter 4) calls factitious vice-whereby someone acts viciously not because he has bad character but because he thinks everyone expects him to behave so. The novel depicts Bigger Thomas, a young African American man living in poverty in Chicago during the 1930's. Shaped by racism and humiliation, Bigger is finally driven to commit heinous crimes, including the murder of his employer and of his partner Bessie Mears. While the novel does not invite the reader to absolve Bigger of his crimes, it does suggest that we should regard Bigger's actions as 
driven by society's brutal expectations of black youth. Discussing Franz Fanon's analysis of the novel, Harold Bloom writes that "Bigger is meant to terrify us, and he does, but Wright has the skill to show us that all too frequently Bigger acts out of intense fear, a realistic terror of the world. [. . .] Bigger kills only as a response to the world's expectation that he must kill or die" $(2007,9)$. The novel movingly dramatizes how attributions of negative traits can lead to behavior that then seems to confirm the attributions.

A more recent example in a different genre, the $\mathrm{HBO}$ television series The Wire, dramatizes the effects of negative expectations on child development. The series centers on the drug epidemic in Baltimore, and season four is devoted to its impact on the school system. Many students are so-called corner boys, pulled into the drug trade at a young age. One adult character, Howard "Bunny" Colvin, expresses a genuine understanding of how expectations can function as self-fulfilling prophecies. In episode nine, he says of these children, "They're not fools. They know exactly what we expect them to be." And in the next episode, he tells a school administrator,

You put a textbook in front of these kids, put a problem on the blackboard, or teach them every problem on some statewide test, it won't matter. None of it. 'Cuz they're not learning for our world. They're learning for theirs. And they know exactly what it is they're training for, and what it is everyone expects them to be.

As Colvin anticipates, most of the corner boys end up on the street engaged in the drug business. The most striking counterexample is Naymond Brice, the son of a member of the Barksdale drug cartel. Colvin makes his positive expectations clear to Brice, which in turn make possible the boy's eventual escape from his imprisoned father, his anti-social mother, and the total social context in which he was raised and which had communicated its sinister expectations to him. 
Examples such as these show how effectively interactionist cognitivism meets the situationist challenge. Artists are not limited to depicting moral examplars or exaggerated versions of character. They can also illustrate how situational influences partially govern behavior. Furthermore, they can dramatize how easy it is to fabricate evidence for character where no evidence or contrary evidence exists, a phenomenon known in social psychology as the fundamental attribution error (Ross 1977). Austen is a master of this device, as the subplot involving George Wickham in Pride and Prejudice illustrates. With his charming manners, Wickham not only manages to impress the other characters with his rectitude, but also to slander Fitzwilliam Darcy's character. Through both subtle insinuation and overt gossip, he induces society to view him as a martyr to Darcy's pride.

\section{Conclusion}

We have attempted to show how the situationist challenge to virtue ethics, if successful, creates parallel problems for virtue-based moral cognitivism in philosophy of art. The key question is: what (if anything) is the moral content of the cognitive value of art? We have argued that evidence from situationist social psychology arguably reveals the moral content of narrative art regarding virtue and vice to be false — or at least misleading and incomplete. We then proposed a view a novel view of the moral content of art, interactionist cognitivism, according to which part of art's cognitive value lies in its capacity to educate regarding the interaction of personality and situation. ${ }^{11}$

\footnotetext{
${ }^{11}$ With thanks to Noël Carrol, Brian Robinson, and Markus Christen for helpful comments on earlier drafts. We are also grateful to the audiences at Character: An Interdisciplinary Panel
} 


\section{References}

Adams, Robert Merrihew. 2006. A Theory of Virtue: Excellence in Being for the Good, Oxford University Press.

Alfano, Mark 2011. "Explaining Away Intuitions about Traits: Why Virtue Ethics Seems Plausible (Even if it isn’t),” Review of Philosophy and Psychology 2 (1): 121-136.

- - 2012. "Extending the Situationist Challenge to Responsibilist Virtue Epistemology," Philosophical Quarterly 62 (247): 223-249.

- - 2013. Character as Moral Fiction, Cambridge, UK: Cambridge University Press.

- - 2015. "Becoming Less Unreasonable: A Reply to Sherman,” Social Epistemology Review and Reply Collective 4(7): 59-62.

Annas, Julia 2011. Intelligent Virtue, Oxford University Press.

Arkin, Robert, Kathryn Oleson, and John Darley 1998. "Self-Handicapping,” in John McConnon and Joel Cooper (editors), Attribution and Social Interaction: The Legacy of Edward E. Jones, pp. 313-71. Washington, DC: American Psychological Association.

Austen, Jane 1818/2012. Persuasion, New York: Tribeca Books.

Badhwar, Neera 2009. "The Milgram Experiments, Learned Helplessness, and Character Traits," Journal of Ethics 13 (2-3): 257-289.

Aristotle 1984. The Complete Works of Aristotle, Volumes 1 and 2, J. Barnes, ed., Princeton, NJ: Princeton University Press.

(Notre Dame, 2012) and the annual meeting of the Long Island Philosophical Society (2009) for discussion of these issues - and especially John DeCarlo for his commentary. 
Beardsley, Monroe 1958. Aesthetics: Problems in the Philosophy of Criticism, New York: Harcourt, Brace and World.

Berkowitz, Leonard, ed., 1977. Advances in Experimental Social Psychology, Volume 10, New York: Academic Press.

Bloom, Harold 2007. Bloom's Guides: Richard Wright's Native Son, New York: Infobase Publishing.

Camus, Albert 1942/1946. The Stranger, trans. S. Gilbert, New York: Random House.

Carroll, Noël 1998. “Art, Narrative, and Moral Understanding,” in J. Levinson, ed., (1999, 126$160)$.

- - - 2002. "The Wheel of Virtue: Art, Literature, and Moral Knowledge," The Journal of Aesthetics and Art Criticism 60(1): 3-26.

- - 2013. Minerva's Night Out: Philosophy, Pop Culture, and Moving Pictures, Malden, MA: Wiley Blackwell.

Conolly, Oliver and Bashshar Haydar 2001. "Narrative Art and Moral Knowledge,” British Journal of Aesthetics 41 (2): 109-124.

Currie, Gregory. 1995. “The Moral Psychology of Fiction,” Australasian Journal of Philosophy 73 (2): 250-259.

Darley, John and Daniel Batson 1973. "From Jerusalem to Jericho: A Study of Situational and Dispositional Variables in Helping Behavior," Journal of Personality and Social Psychology 27: 100-108.

Doris, John 1998. “Persons, Situations, and Virtue Ethics,” Noûs 32 (4): 504-540.

- - 2002. Lack of Character: Personality and Moral Behavior, Cambridge, UK: Cambridge University Press. 
Funder, David and Daniel Ozer 1983. "Behavior as a Function of the Situation,” Journal of Personality and Social Psychology 44: 107-112.

Gaut, Berys 2006. “Art and Cognition,” in M. Kieran, ed., (2006, 115-126).

Gollwitzer, Peter 1999. “Implementation Intentions,” American Psychologist 54: 493-503.

Graham, Gordon 1996. “Aesthetic Cognitivism and the Literary Arts,” Journal of Aesthetic Education 30 (1): 1-17.

Harman, Gilbert 1999. "Moral Philosophy Meets Social Psychology: Virtue Ethics and the Fundamental Attribution Error,” Proceedings of the Aristotelian Society 119: 316-331.

- - 2000. "The Nonexistence of Character Traits," Proceedings of the Aristotelian Society 100: 223-226.

Hursthouse, Rosalind 1999. On Virtue Ethics, Oxford: Oxford University Press.

Hutto, Daniel 2008. Folk Psychological Narratives: The Sociocultural Basis of Understanding Reasons, Cambridge, MA: MIT Press.

Kant, Immanuel 1790/1952. The Critique of Judgment, trans. J. C. Meredith Oxford: Oxford University Press.

Kieran, Matthew 1996. "Art, Imagination and the Cultivation of Morals," Journal of Aesthetics and Art Criticism 54 (4): 337-51.

- - - 2005. Revealing Art, London: Routledge.

- - -, ed. 2006. Contemporary Debates in Aesthetics and the Philosophy of Art, Oxford: Blackwell.

- - - 2010. "The Vice of Snobbery: Aesthetic Knowledge, Justfication and Virtue in Art Appreciation," The Philosophical Quarterly 60 (239): 243-263.

Levinson, Jerrold, ed. 1998. Aesthetics and Ethics, Cambridge, UK: Cambridge University Press. 
Lopes, Dominic McIver 2008. "Virtues of Art: Good Taste," Proceedings of the Aristotelian Society Supplementary Volume, LXXXII: 197-211.

Mele, Alfred and Joshua Shepherd 2013. "Situationism and Agency," Journal of Practical Ethics 1 (1): $62-83$.

Milgram, Stanley 1974. Obedience to Authority, New York: Harper Collins.

Miller, Christian 2003. "Social Psychology and Virtue Ethics," The Journal of Ethics 7 (4): 365392.

- - - 2009. "Empathy, Social Psychology, and Global Helping Traits," Philosophical Studies 142 (2): 247-275.

Mischel, Walter 1968. Personality and Assessment, New York: Wiley.

Morton, Adam. 2013. Emotion and Imagination, Malden, MA: Polity Press.

Nagy, Gregory 1979. The Best of the Acheans, Johns Hopkins Press, 1979.

Nussbaum, Martha 1996. Poetic Justice: The Literary Imagination and Public Life, Boston: Beacon Press.

Rauthmann, John, David Gallardo-Pujol, Esther Guillaume, Elysia Todd, Christopher Nave, Ryne Sherman, Matthias Ziegler, Ashley Jones, and David Funder 2014. “A Taxonomy of Major Dimensions of Situational Characteristic, Journal of Personality and Social Psychology" 107(4): 677-718.

Reynolds, Katherine, John Turner, Nyla Branscombe, Kenneth Mavor, Boris Bizumic, and Emina Subašić 2010. "Interactionism in Personality and Social Psychology: An Integrated Approach to Understanding the Mind and Behavior," European Journal of Personality 24 (5): 458-482. 
Ross, Lee 1977. "The Intuitive Psychologist and His Shortcomings: Distortions in the Attribution Process,” in L. Berkowitz, ed., (1977, 173-220).

Swanton, Christine 2003. Virtue Ethics: A Pluralist View, Oxford: Oxford University Press. Young, James O. 2001. Art and Knowledge, London: Routledge.

Zagzebski, Linda. Forthcoming. Exemplarist Virtue Theory, New York: Oxford University Press. 